\title{
ANTIPLASMODIAL ACTIVITY OF KETOTIFEN-ARTEMETHER- LUMEFANTRINE ON PLASMODIUM BERGHEI INFECTED MICE
}

\author{
Georgewill Udeme Owunari ${ }^{* 1}$ (iD , Ezerioha Chidi Emmanuel ${ }^{1}$ iD , Adikwu Elias ${ }^{2}$ \\ (iD) \\ ${ }^{* 1}$ Department of Pharmacology, Faculty of Basic Medical Sciences, University of Port Harcourt, \\ Rivers State, Nigeria \\ 2 Department of Pharmacology and Toxicology, Faculty of Pharmacy, Niger Delta University, \\ Bayelsa State, Nigeria
}

DOI: https://doi.org/10.29121/granthaalayah.v8.i11.2020.2439

Article Type: Research Article

Article Citation: Georgewill Udeme Owunari, Ezerioha Chidi Emmanuel, and Adikwu Elias. (2020).

ANTIPLASMODIAL ACTIVITY OF KETOTIFEN-ARTEMETHERLUMEFANTRINE ON PLASMODIUM BERGHEI INFECTED MICE. International Journal of Research GRANTHAALAYAH, 8(11), 251-258. https://doi.org/10.29121/granthaa layah.v8.i11.2020.2439

Received Date: 10 October 2020

Accepted Date: 30 November 2020

Keywords:

Ketotifen

Artemether/Lumefantrine Antiplasmodium

Mice

\section{ABSTRACT}

Introduction: The development of new antimalarial drugs is timeconsuming and costly, thus repurposing of drugs with initial indications for possible antimalarial indication is imperative. This study assessed the antiplasmodial effect of ketotifen (KT) in combination with artemether/lumefantrine (A/L) in Plasmodium bergei infected mice.

Materials and Methods: Adult mice (25-30g) were parasitized with Plasmodium berghei, grouped and treated per oral (p.o) with KT $(0.1 \mathrm{mg} / \mathrm{kg}), \mathrm{A} / \mathrm{L}(2.3 / 13.7 \mathrm{mg} / \mathrm{kg})$ and $\mathrm{KT} / \mathrm{A} / \mathrm{L}$ daily in curative, suppressive and prophylactic studies. The negative control (NC) and the positive control (PC) were treated daily p.o with normal saline $(0.2 \mathrm{~mL})$ and chloroquine (CQ) $(10 \mathrm{mg} / \mathrm{kg})$ for 4 days respectively. After treatment, blood samples were collected and assessed for percentage parasitemia level, hematological and lipid parameters.

Results: The curative, suppressive and prophylactic studies showed significant decreases in percentage parasitemia levels at $\mathrm{KT}(0.1 \mathrm{mg} / \mathrm{kg})$ $(\mathrm{p}<0.01), A / \mathrm{L}(2.3 / 13.7 \mathrm{mg} / \mathrm{kg})(\mathrm{p}<0.001)$ and KT/A/L $(\mathrm{p}<0.0001)$ when compared to negative control. Significant increases in mean survival times occurred at KT $(0.1 \mathrm{mg} / \mathrm{kg})(\mathrm{p}<0.01), \mathrm{A} / \mathrm{L}(2.3 / 13.7 \mathrm{mg} / \mathrm{kg})(\mathrm{p}<0.001)$ and A/L/T $(p<0.0001)$ when compared to negative control. Significant increases in packed cell volume, red blood cells, hemoglobin, high density lipoprotein cholesterol levels with significant decreases in total cholesterol, white blood cells, low density lipoprotein cholesterol and triglyceride levels at KT $(28.6 \mathrm{mg} / \mathrm{kg})(\mathrm{p}<0.05), \mathrm{A} / \mathrm{L}(2.3 / 13.7 \mathrm{mg} / \mathrm{kg})$ $(\mathrm{p}<0.01)$ and KT/A/L $(\mathrm{p}<0.001)$ when compared to negative control.

Conclusion: KT may be repurposed in combination with A/L for malaria treatment.

\section{INTRODUCTION}

Malaria is among the ailments ravaging the human race and its manifestations could be severe and lifethreatening. Its major impact is most experienced in developing countries [1]. In 2018, malaria infection was 228 million which accounted for over 405,000 deaths mostly in developing nations. The impact of malaria and its 
consequences is predominant in children below the age of five and pregnant women which poses significant health challenges [2]. Efforts to eradicate malaria have experienced setbacks due to challenges including the emergence of insecticide-resistant mosquitoes, drug-resistant parasites and lack of drugs or vaccines to block parasite transmission [3]. Drug resistance has remarkably increased causing changes in malaria treatment from chloroquine (CQ) to artemisinin-based combination therapies (ACTs), which are currently preferred for malaria treatment. Despite the antimalarial impact of ACTs, setbacks due to cost and emergence of resistant parasites herald the need for newer antimalarial drugs with different modes of action and different structural features [4].

One of the strategies to discover new antimalarials is to reposition, or repurpose drugs that are already used for other indications [5]. This approach, as compared to the "de novo" drug discovery process has advantages such as reduced cost and short time of drug development [5]. Repurposed drugs have well-documented toxicity, pharmacology and drug-drug interaction profile. Drug repurposing is based on the principle of polypharmacology; a paradigm in drug discovery where a drug with multiple targets and off-target effects may have multiple mechanisms of action [6]. The repositioning of drugs with good safety profiles will gain quick approval for newer indications using the same route of administration [7]. It is encouraging that drug regulatory associations in Europe and USA have launched drug repurposing programs to identify new uses for existing medications [8].

Ketotifen (KT), a tricyclic benzocycloheptathiophene derivate, is broadly used for allergies, asthma, and inflammatory disorders. It blocks $\mathrm{H}_{1}$ receptors, stabilizes mast cells, and inhibits eosinophil accumulation and degranulation that results in the further stabilization of the cell membrane [9]. It is well absorbed after oral administration, with peak plasma drug concentrations within 2 to $4 \mathrm{~h}$ [10]. In a recent study both KT and its metabolite norketotifen were shown to be active against schizonts and liver-stage $P$. berghei parasites [11]. KT and other antihistamines have been shown to be effective in reversing CQ resistance in P. falciparum [12], [13] and P. yoelii nigeriensis [14]. It shows higher potency in blocking oocyst formation in mice, which suggests that KT may act more effectively on mosquito stages of fertilization. KT affects gamete production by decreasing P. falciparum gametocytes and greatly reduced the numbers of exflagellation centers [3]. Study shows the possible role of KT in the treatment of $P$. falciparum associated malaria in combination with CQ [15].This study, assessed the antiplasmodial activity of KT in combination with artemether/ lumefantrine (A/L) in P. berghei infected mice

\section{MATERIALS AND METHODS}

\subsection{EXPERIMENTAL ANIMALS AND MALARIA PARASITE}

Wistar mice weighing 25-30g were used. The mice were bought from the animal house of the Department of Pharmacology, University of Port-Harcourt, Nigeria. The mice were kept in cages and allowed to acclimatize for 2 weeks before the study began. The mice were fed with food and water ad libitum. P. berghei was obtained from the Malaria Research Laboratory, Centre for Malaria Research and Phytomedicine, University of Port-Harcourt, Nigeria. The directive (2010/63/EU) of the European Union Parliament and the Council on the handling of laboratory animals for scientific purposes was used for this study.

\subsection{DRUGS}

Ketotifen (KT) (Sun Pharm Industries Ltd, India), artemether/lumefantrine (A/L) (IPCA Laboratories Ltd), and Chloroquine (CQ) (Evans Medical Nigeria Plc) were used for this study. A/L (2.3/13.7 mg/kg) [16], Ketotifen (0.1 $\mathrm{mg} / \mathrm{kg})[17]$ and CQ (10mg/kg) [18] were used.

\subsection{PARASITE INOCULATION}

Blood samples from mice were first screened to ascertain that they were parasite free. Stock inoculum of $1 \mathrm{x}$ $10^{7} \mathrm{P}$. berghei infected erythrocytes in $0.2 \mathrm{~mL}$ was prepared by diluting portions of the blood infected with P. berghei with $0.9 \%$ normal saline. This was inoculated into each mouse via intra-peritoneal route of administration. 


\subsection{CURATIVE TEST}

The method proposed by Ryley and Peters (1970) [19] was used for this study. Thirty mice (Groups I-VI) were used. Groups 11-VI were inoculated with $1 \times 10^{7} P$. berghei parasitized erythrocytes intraperitoneally (i.p). After 72 hours (3 days), the mice were treated as follows. Group I (Non-parasitized) (Normal control), and group 11 (Negative control) were treated with normal saline $(0.2 \mathrm{~mL})$ respectively. Group III (Positive control) was treated with CQ $(10 \mathrm{mg} / \mathrm{kg})$ whereas groups IV - V1 were treated with KT $(0.1 \mathrm{mg} / \mathrm{kg}), \mathrm{A} / \mathrm{L}(1.1 / 4.6 \mathrm{mg} / \mathrm{kg})$ and KT $/ \mathrm{A} / \mathrm{L}$ for 4 days respectively. On day 5 , tail blood samples were collected and thin blood films were made on microscope slides. The films were fixed with methanol and stained with $10 \%$ Giemsa stain for 30 minutes. The stained thin blood films were viewed under oil immersion x100 magnification and the number of parasitized red blood cells were counted against the total number of red blood cells in a field and percentage parasitemia calculated using the formula shown below.

\subsection{SUPPRESSIVE TEST}

This test was conducted for four days as reported by Knight and Peters (1980) [20]. The mice were inoculated i.p with blood sample $(0.2 \mathrm{~mL})$ containing $1 \times 10^{7}$ P.berghei. Afterward, the mice were randomized into 5 groups of five mice. After 3 hours, the mice were treated. Group I (Negative control) was treated daily with normal saline $(0.2 \mathrm{~mL})$ whereas group II (Positive control) was treated with CQ $(10 \mathrm{mg} / \mathrm{kg})$ for 4 days. Groups III - V were treated daily with KT $(0.1 \mathrm{mg} / \mathrm{kg}), \mathrm{A} / \mathrm{L}(1.1 / 4.6 \mathrm{mg} / \mathrm{kg})$ and KT/A/L for 4 days respectively. On day 5, blood samples were collected, films were prepared and percentage parasitemia determined using the formula below

\subsection{PROPHYLACTIC TEST}

This was evaluated according to Peters (1965) [21]. Twenty five mice were randomized into 5 groups of five mice each. Group I (Negative control) and group II (Positive control) were administered daily with normal saline $(0.2 \mathrm{~mL})$ and CQ $(10 \mathrm{mg} / \mathrm{kg})$ respectively. Groups III $-\mathrm{V}$ were administered daily with $\mathrm{KT}(0.1 \mathrm{mg} / \mathrm{kg}), \mathrm{A} / \mathrm{L}$ $(1.1 / 4.6 \mathrm{mg} / \mathrm{kg})$ and KT/A/L respectively. On day 4, the mice were infected i.p. with $1 \times 10^{7} P$. berghei parasitized erythrocytes and treatment continued for 4 days. Blood samples were collected from the tail on day 5 and day 7 and percentage parasitemia determined using the formula below

$$
\begin{aligned}
& \% \text { Parasitemia }=\frac{\text { Total number of parasitized } R B C}{\text { Total number of } R B C} \times 100 \\
& \% \text { Inhibition }=\frac{\text { (Mean parasitemia of negative control-Mean parasistemia of treated groups) }}{\text { Mean parasitemia of negative control }} \times 100
\end{aligned}
$$

\subsection{DETERMINATION OF MEAN SURVIVAL}

During the study, the mice were observed for mortality which was determined as mean (MST) in days using the formula below

$$
\text { MST }=\frac{\text { Sum of survival time }(\text { days }) \text { of all the mice in the group }}{\text { Total number of mice in that group }}
$$

\subsection{EVALUATION OF HEMATOLOGICAL AND LIPID PARAMETERS}

Blood samples from the curative test were evaluated for Red blood cell (RBC), hemoglobin (HB), pack cell volume (PCV), high density lipoprotein cholesterol (HDL-C), white blood cell (WBC), triglyceride (TG), total cholesterol (CHOL) and high density lipoprotein cholesterol (LDL-C) levels using an auto analyzer 
Antiplasmodial Activity of Ketotifen-Artemether-Lumefantrine on Plasmodium Berghei Infected Mice

\subsection{DATA ANALYSIS}

Data was analyzed using GraphPad prism 6.0 statistical software. Data was presented as Mean \pm SEM. Significant difference was considered using one-way analysis of variance (ANOVA) followed by Tukey's post-hoc test. Significance was considered at $\mathrm{p}<0.05 ; \mathrm{p}<0.01$ and $\mathrm{p}<0.001$.

\section{RESULTS}

\subsection{CURATIVE TEST}

Curative test showed significant decreases in percentage parasitemia at $p<0.01$ and $p<0.001$ in mice treated with individual doses of KT and A/L respectively when compared to negative control. However, most significant reduction in percentage parasitemia level at $\mathrm{p}<0.0001$ occurred in mice treated with KT/A/L when compared to negative control. The observed decrease in percentage parasitamia in KT/A/L treated mice differ $(\mathrm{p}<0.05)$ when compared to CQ-treated mice (Table 1). Percentage parasitemia inhibition were $62.5 \%$ and $73.7 \%$ in rats treated with individual doses of KT and A/L with observed significance at $\mathrm{p}<0.01$ and $\mathrm{p}<0.001$ respectively when compared to negative control. On the other hand, $90.0 \%$ parasitemia inhibition was observed in KT/A/L treated mice which differ at $\mathrm{p}<0.0001$ when compared to negative control (Table 1). Treatment with KT, AL, KT/A/L significantly increased MST at $\mathrm{p}<0.05, \mathrm{p}<0.01$, and $\mathrm{p}<0.001$ respectively when compared to negative control (Table 1 ).

\subsection{SUPPRESSIVE TEST}

In the suppression test, individual doses of $\mathrm{KT}$ and $\mathrm{A} / \mathrm{L}$ produced significant reductions in percentage parasitemia levels at $\mathrm{p}<0.01$ and $\mathrm{p}<0.001$ respectively when compared to negative control. On the hand, KT/A/L produced most significant reduction in percentage parasitemia level at $\mathrm{p}<0.001$ when compared to negative control. Comparatively, reduction in percentage parasitemia produced by A/L/KF differ $(\mathrm{p}<0.05)$ from CQ (Table 2). Treatment with KT, A/L and KT/A/L produced $68.0 \%, 75.0 \%$ and $91.9 \%$ percentage parasitemia inhibitions respectively (Table 2). MST was significantly increased in mice treated with KT ( $<<0.05), A / L(p<0.01)$ and KT/A/L $(\mathrm{p}<0.0001)$ when compared to negative control (Table 2).

\subsection{PROPHYLACTIC TEST}

Treatment with individual doses of KT and A/L produced significant time-dependent reductions in percentage parasitemia levels on day 5 and 7 when compared to negative control. However, treatment with KT/A/L produced most significant time-dependent reductions in percentage parasitemia levels on day 5 and day 7 when compared to negative control (Table 3). On day 7, individual doses of KT and A/L produced 84.4\% and 89.4 \% percentage parasitemia inhibition respectively, KT/A/L produced 99.3 percentage parasitemia inhibition whereas CQ (Positive control) produced $91.8 \%$ percentage parasitemia inhibition (Table 3). MST was significantly increased in mice treated with KT $(\mathrm{p}<0.05), \mathrm{A} / \mathrm{L}(\mathrm{p}<0.01)$ and KT/A/L $(\mathrm{p}<0.001)$ when compared to negative control (Table 2).

\subsection{EFFECTS ON HEMATOLOGICAL AND LIPID PARAMETERS}

The negative control shows significant decreases in RBC, HB, PCV and HDL levels with increases in WBC, TG, CHOL, LDL-C levels when compared to non-parasitized rats (normal control). In contrast, RBC, HB, PCV were significantly increased whereas WBC, TG, CHOL, LDL-C were significantly decreased at $\mathrm{p}<0.01$ and $\mathrm{p}<0.001$ by KT and A/L respectively when compared to negative control (Tables 4 and 5). However, KT/A/L produced most significant increases in RBC, HB, PCV and HDL-C levels with decreases in WBC, TG, CHOL, LDL-C levels ( $<<0.0001)$ when compared to negative control (Tables 4 and 5). The observed effects produced by KT/A/L on RBC, HB, PCV, HDL-C, WBC, TG, CHOL, LDL-C levels differ $(\mathrm{p}<0.05)$ when compared to CQ (Tables 4 and 5). 
Table 1: Curative activity of ketotifen and its combination with artemether/ lumefantrine on Plasmodium berghei-infected mice

\begin{tabular}{|c|c|c|c|}
\hline Group & Parasitemia (\%) & MST & Inhibition (\%) \\
\hline NC & $22.8 \pm 0.59$ & $7.75 \pm 0.85$ & - \\
\hline CQ & $5.85 \pm 0.21 \mathrm{a}$ & $25.0 \pm 2.03 \mathrm{~b}$ & 74.3 \\
\hline KT & $8.55 \pm 0.19 \mathrm{~b}$ & $20.5 \pm 2.29 \mathrm{~d}$ & 62.5 \\
\hline A/L & $6.00 \pm 0.22 \mathrm{a}$ & $26.0 \pm 2.05 \mathrm{~b}$ & 73.7 \\
\hline KT /A/L & $2.28 \pm 0.25 \mathrm{~cd}$ & $31.0 \pm 1.92 \mathrm{a}$ & 90.0 \\
\hline
\end{tabular}

NC: Negative Control; CQ: Chloroquine; KT: Ketotifen; A/L: Artemether /Lumefantrine; KT/A/L: Ketotifen/Artemether/Lumefantrine; MST: Mean Survival Time; $n=5$; Data expressed as mean \pm SEM, a $p<0.001$ when compared to $\mathrm{NC}$; ${ }^{\mathrm{b}} \mathrm{p}<0.01$ when compared to $\mathrm{NC} ;{ }^{\mathrm{c}} \mathrm{p}<0.0001$ when compared to $\mathrm{NC}$; ${ }^{\mathrm{d}} \mathrm{p}<0.05$ when compared to CQ.

Table 2: Suppressive activity of Ketotifen and its combination with artemether/lumefantrine on Plasmodium berghei-infected mice

\begin{tabular}{|c|c|c|c|}
\hline Group & Parasitemia (\%) & MST & Inhibition (\%) \\
\hline NC & $12.5 \pm 1.73$ & $8.00 \pm 1.08$ & - \\
\hline CQ & $2.40 \pm 0.10^{\mathrm{a}}$ & $28.0 \pm 3.22^{\mathrm{b}}$ & 80.8 \\
\hline KT & $4.00 \pm 0.29^{\mathrm{b}}$ & $22.7 \pm 1.11^{\mathrm{d}}$ & 68.0 \\
\hline A/L & $3.12 \pm 0.19^{\mathrm{a}}$ & $28.2 \pm 2.52^{\mathrm{b}}$ & 75.0 \\
\hline KT/A/L & $1.01 \pm 0.21^{\mathrm{cd}}$ & $35.0 \pm 3.68^{\mathrm{a}}$ & 91.9 \\
\hline
\end{tabular}

NC: Negative Control; CQ: Chloroquine; KT: Ketotifen; A/L: Artemether /Lumefantrine; KT/A/L: Ketotifen/Artemether/Lumefantrine; MST: Mean Survival Time; $n=5$; Data expressed as mean \pm SEM, a $p<0.001$ when compared to $\mathrm{NC}$; ${ }^{\mathrm{b}} \mathrm{p}<0.01$ when compared to $\mathrm{NC}$; ${ }^{\mathrm{c}} \mathrm{p}<0.0001$ when compared to $\mathrm{NC}$; ${ }^{\mathrm{d}} \mathrm{p}<0.05$ when compared to CQ.

Table 3: Prophylactic activity of ketotifen and its combination with artemether/ lumefantrine on Plasmodium berghei-infected mice

\begin{tabular}{|c|c|c|c|c|c|}
\hline Group & $\begin{array}{c}\text { Parasitemia (\%) } \\
\text { Day 5 }\end{array}$ & $\begin{array}{c}\text { Inhibition (\%) } \\
\text { Day 5 }\end{array}$ & $\begin{array}{c}\text { Parasitemia (\%) } \\
\text { Day 7 }\end{array}$ & $\begin{array}{c}\text { Inhibition (\%) } \\
\text { Day 7 }\end{array}$ & MST \\
\hline NC & $9.80 \pm 0.93$ & & $16.5 \pm 1.07$ & - & $8.00 \pm 0.47$ \\
\hline CQ & $1.80 \pm 0.29^{\mathrm{a}}$ & 81.6 & $1.35 \pm 0.14^{\mathrm{a}}$ & 91.8 & $30.7 \pm 2.33^{\mathrm{b}}$ \\
\hline KT & $3.00 \pm 0.48^{\mathrm{b}}$ & 69.3 & $2.58 \pm 0.24^{\mathrm{b}}$ & 84.4 & $22.9 \pm 2.91^{\mathrm{d}}$ \\
\hline A/L & $2.20 \pm 0.61^{\mathrm{a}}$ & 77.5 & $1.75 \pm 0.14^{\mathrm{a}}$ & 89.4 & $26.4 \pm 3.44^{\mathrm{b}}$ \\
\hline KT/A/L & $0.21 \pm 0.50^{\mathrm{cd}}$ & 95.9 & $0.10 \pm 0.16^{\mathrm{cd}}$ & 99.3 & $34.5 \pm 2.18^{\mathrm{a}}$ \\
\hline
\end{tabular}

NC: Negative Control; CQ: Chloroquine; KT: Ketotifen; A/L: Artemether /Lumefantrine; KT/A/L: Ketotifen/Artemether/Lumefantrine; MST: Mean Survival Time; $n=5$; Data expressed as mean \pm SEM, a $p<0.001$ when compared to $\mathrm{NC}$; ${ }^{\mathrm{b}} \mathrm{p}<0.01$ when compared to $\mathrm{NC}$; ${ }^{\mathrm{c}} \mathrm{p}<0.0001$ when compared to $\mathrm{NC}$; ${ }^{\mathrm{d}} \mathrm{p}<0.05$ when compared to $\mathrm{CQ}$.

Table 4: Effect of ketotifen and its combination with artemether/lumefantrine on lipid profile of Plasmodium berghei-infected mice

\begin{tabular}{|c|c|c|c|c|}
\hline Treatment & TG (mg/dL) & CHOL $(\mathrm{mg} / \mathrm{dL})$ & HDL-C $(\mathrm{mg} / \mathrm{dL})$ & LDL-C $(\mathrm{mg} / \mathrm{dL})$ \\
\hline MC & $114.1 \pm 7.03$ & $156.3 \pm 9.21$ & $56.1 \pm 2.91$ & $77.2 \pm 5.33$ \\
\hline NC & $300.5 \pm 11.2$ & $371.1 \pm 14.2$ & $23.9 \pm 1.26$ & $287.6 \pm 11.3$ \\
\hline CQ & $184.0 \pm 8.87 \mathrm{a}$ & $228.2 \pm 12.2^{\mathrm{a}}$ & $50.1 \pm 1.92^{\mathrm{a}}$ & $141.7 \pm 10.5^{\mathrm{a}}$ \\
\hline KT & $230.4 \pm 6.39^{\mathrm{b}}$ & $270.0 \pm 11.0^{\mathrm{b}}$ & $40.9 \pm 1.82^{\mathrm{b}}$ & $183.0 \pm 9.67^{\mathrm{b}}$ \\
\hline AL & $200.4 \pm 9.01^{\mathrm{a}}$ & $247.7 \pm 10.1^{\mathrm{a}}$ & $48.7 \pm 1.51^{\mathrm{a}}$ & $159.5 \pm 10.4^{\mathrm{a}}$ \\
\hline KT/A/L & $138.7 \pm 5.91^{\mathrm{cd}}$ & $174.9 \pm 12.9^{\mathrm{cd}}$ & $53.7 \pm 2.52^{\mathrm{a}}$ & $93.7 \pm 7.61^{\mathrm{cd}}$ \\
\hline
\end{tabular}


Antiplasmodial Activity of Ketotifen-Artemether-Lumefantrine on Plasmodium Berghei Infected Mice

MC: Normal control; NC: Negative control; CQ: Chloroquine; KT: Ketotifen A/L: Artemether/lumefantrine, KT/A/L: Ketotifen/Artemether/Lumefantrine; TG: Triglyceride; CHOL: Total cholesterol; HDL-C: High density lipoprotein cholesterol; LDL-C: Low density lipoprotein cholesterol; $n=5$; Values are expressed as $M \pm S E M$, a $p<0.01$ when compared to $\mathrm{NC}$; ${ }^{\mathrm{b}} \mathrm{p}<0.05$ when compared to $\mathrm{NC}$; ${ }^{\mathrm{c}} \mathrm{p}<0.001$ when compared to $\mathrm{NC}$; ${ }^{\mathrm{d}} \mathrm{p}<0.01$ when compared to CQ.

Table 5: Effect of ketotifen and its combination with artemether/lumefantrine on hematological parameters of Plasmodium berghei-infected mice

\begin{tabular}{|c|c|c|c|c|}
\hline Treatment & $\mathrm{RBC}\left(\times 10^{6} / \mu \mathrm{l}\right)$ & $\mathrm{WBC}\left(\times 10^{3} / \mu \mathrm{l}\right)$ & $\mathrm{PCV}(\%)$ & $\mathrm{Hb}(\mathrm{g} / \mathrm{dl})$ \\
\hline MC & $5.45 \pm 0.18$ & $5.35 \pm 0.17$ & $63.5 \pm 2.22$ & $18.1 \pm 0.91$ \\
\hline NC & $2.29 \pm 0.13$ & $11.1 \pm 0.32$ & $24.0 \pm 2.04$ & $8.45 \pm 0.52$ \\
\hline CQ & $4.45 \pm 0.19^{\mathrm{a}}$ & $6.69 \pm 0.18^{\mathrm{a}}$ & $55.2 \pm 3.32^{\mathrm{a}}$ & $14.7 \pm 0.77^{\mathrm{a}}$ \\
\hline KT & $3.29 \pm 0.17 \mathrm{~b}$ & $8.85 \pm 0.19^{\mathrm{b}}$ & $41.0 \pm 3.43^{\mathrm{b}}$ & $11.4 \pm 0.52^{\mathrm{b}}$ \\
\hline A/L & $4.21 \pm 0.22^{\mathrm{a}}$ & $6.80 \pm 0.21^{\mathrm{a}}$ & $52.7 \pm 3.21^{\mathrm{a}}$ & $14.1 \pm 0.59^{\mathrm{a}}$ \\
\hline KT/A/L & $5.33 \pm 0.21^{\mathrm{cd}}$ & $5.00 \pm 0.16^{\mathrm{cd}}$ & $60.4 \pm 3.81^{\mathrm{cd}}$ & $17.5 \pm 0.83^{\mathrm{cd}}$ \\
\hline
\end{tabular}

MC: Normal control; NC: Negative control; CQ: Chloroquine; KT: Ketotifen, A/L: Artemether/lumefantrine, KT/A/L: Ketotifen/Artemether/Lumefantrine; TG: Triglyceride; CHOL: Total cholesterol; HDL-C: High density lipoprotein cholesterol; LDL-C: Low density lipoprotein cholesterol; $n=5$; Values are expressed as $\mathrm{M} \pm \mathrm{SEM}$, , ${ }^{\mathrm{p}} \mathrm{p}<0.01$ when compared to $\mathrm{NC}$; ${ }^{\mathrm{b}} \mathrm{p}<0.05$ when compared to $\mathrm{NC}$; ${ }^{\mathrm{c}} \mathrm{p}<0.001$ when compared to $\mathrm{NC}$; ${ }^{\mathrm{d}} \mathrm{p}<0.01$ when compared to CQ.

\section{DISCUSSION}

Drug development is a long and complex process. It is capital intensive with no guarantee of success. In recent years, there was a significant decline in the number of new drugs approved for clinical use. This necessitates the repurposing of already approved drugs, for new indications other than their initial indications. This strategy reduces costs and research time considerably [22]. This study evaluated the possibility of repurposing KT as an antimalarial drug in combination with A/L on P. berghei infected mice. The rodent parasite; P. berghei has been used for studying the activity of antimalarial drug candidates in mice [23]. Rodent models of antimalarial study have been validated through the identification of several conventional antimalarial drugs including quinine and more recently artemisinin derivatives [24]. The in vivo antiplasmodial activity of KT/A/L was evaluated using curative, suppressive and suppression test which are validated tests for the assessment of antimalarial drug candidates. Percentage parasitemia inhibition and mean survival time were calculated from the curative, suppression, and prophylatic tests with reference to other studies [25], [26]. In this study, antiplasmodial evaluation of KT/A/L showed reductions in percentage parasitamia levels with increased percentage parasitemia inhibition in the suppressive and curative tests. In the prophylactic test, KT/A/L produced time-related reductions in percentage parasitemia levels and increased percentage parasitemia inhibitions. Malaria associated mortality is a challenge that is prevalent in malaria endemic regions primarily developing nations. MST is experimentally used to assess the ability of antimalarial candidate drugs to prevent or reduce mortality in plasmodium parasitized rodents [27]. In this study, KT/A/L increased MST in the suppressive, curative and prophylactic tests better than individual doses of KT and A/L. Anemia is a common malaria complication prevalent in children and pregnant women in malaria endemic regions [28]. $P$. berghei infected mice suffer from anemia because of erythrocyte destruction, either by parasite multiplication or by spleen reticuloendotelial cell action as the presence of many abnormal erythrocytes stimulates the spleen to produce many phagocytes [29]. The current study observed anemia in untreated parasitized mice (Negative control) characterized by decreased RBC, PCV, HB with increased WBC levels. However, KT/A/L produced reduction in anemia characterized by increased RBC, PCV, HB and decreased WBC levels. KT/A/L produced the best effects on the aforementioned biochemical parameters than individual doses of KT and A/L. Emerging studies suggest that routine laboratory measurement of lipids could be a good and reliable adjunct in the early diagnosis of malaria especially in malaria endemic areas [30]. This study observed impaired lipid profile characterized by elevated TG, CHOL, and LDL-C and decreased HDL levels in negative control. This observation is consistent with altered lipid profile reported in previous findings [31]. However, lipid levels were restored in parasitized rats treated with KT/A/L. This study shows that KT may be repurposed in combination with A/L for the treatment of malaria. The 
observation in this study can be correlated with a study that reported improved antimalarial activity when KT was co-administered with CQ [17]. The observation in this study can also be compared with increased antimalarial activity when KT was co-administered with CQ and sulphadoxine/pyrimethamine [15]. The precise mechanism by which KT produced antiplasmodial effect has not been elucidated. However, as an antihistamine, it blocks $\mathrm{H}_{1}$ receptors, stabilizes mast cells, and inhibits eosinophil accumulation and degranulation which further stabilizes cell membrane [9].

\section{CONCLUSION}

This study shows that KT may be repurposed in combination with A/L for the treatment of malaria.

\section{SOURCES OF FUNDING}

This research received no specific grant from any funding agency in the public, commercial, or not-for-profit sectors.

\section{CONFLICT OF INTEREST}

The authors have declared that no competing interests exist.

\section{ACKNOWLEDGMENT}

None.

\section{REFERENCES}

[1] Mandal A. News Medical- Life sciences and Medicine. Malaria Epidemiology. Retrieved from http://www.news-medical.net/health/Malaria-Epidemiology.aspx, 2013.

[2] WHO, "World Health Organization, 2019. World Malaria Report," https://www.who.int/malaria/en/.

[3] Eastman RT, Pattaradilokrat S, Raj DK, Dixit S, Deng B, Miura K et al., A Class of Tricyclic Compounds Blocking Malaria Parasite Oocyst Development and Transmission Antimicrob Agents and Chem, 2013; 57;425-435

[4] Penna-Coutinho J, Aguiar AC, Krettli AU. Commercial drugs containing flavonoids are active in mice with malaria and in vitro against chloroquine-resistant Plasmodium falciparum Mem Inst Oswaldo Cruz, Rio de Janeiro, 113(12): e180279, 2018

[5] Ashburn T.T., Thor K.B. Drug repositioning: identifying and developing new uses for existing drugs. Nat. Rev. Drug Discov. 2004;3(8):673-683

[6] Car B.D. In: Polypharmacology in Drug Discovery. Peters J.-U., editor. Wiley; 2012

[7] Kola I., Landis J. Can the pharmaceutical industry reduce attrition rates? Nat. Rev. Drug Discov. 2004;3(8):711-715

[8] Nowak-Sliwinskaa P, Scapozzaa L, Altaba AR Drug repurposing in oncology: Compounds, pathways, phenotypes and computational approaches for colorectal cancer BBA - Rev on Can 2019; 1871 434-454

[9] Montazeri M, Rezaei K, Ebrahimzadeh MA, Sharif1M, Sarvi1 S, Ahmadpour E, Rahimi MT, Moreira de Oliveira EA, Lang KL, Drug Repositioning: Concept, Classification, Methodology, and Importance in Rare/Orphans and Neglected Diseases Journal of Appl Pharm Sci 2018; 8 (08), 157-165

[10] Grahnen A, Lonnebo A, Beck O, Eckernas SA, Dahlstrom B, Lindstrom B. 1992. Pharmacokinetics of ketotifen after oral administration to healthy male subjects. Biopharm. Drug Dispos. 13:255-262

[11] Milner E, Sousa J, Pybus B, Auschwitz J, Caridha D, Gardner S et al., Ketotifen is an antimalarial prodrug of norketotifen with blood schizonticidal and liver-stage efficacy. Eur. J. Drug Metab. Pharmacokinet. 2012 Mar;37(1):17-22

[12] Basco LK, Ringwald P, Le Bras J. 1991. Chloroquine-potentiating action of antihistaminics in Plasmodium falciparum in vitro. Ann. Trop. Med. Parasitol. 191; 85:223-228. 
[13] Quan H, Tang LH. 2008. In vitro potentiation of chloroquine activity in Plasmodium falciparum by ketotifen and cyproheptadine. Zhongguo Ji Sheng Chong Xue Yu Ji Sheng Chong Bing Za Zhi. 26:338 -342. (In Chinese.)

[14] Singh N, Puri SK. Interaction between chloroquine and diverse pharmacological agents in chloroquine resistant Plasmodium yoelii nigeriensis. Acta Trop. 2000; 77:185-193.

[15] Ibrahim AM, Elhag ER, Mustafa SE. Ketotifen in treatment of uncomplicated falciparum malaria. Saudi Med J. 2000;21(3):257-65

[16] Sirima SB, Ogutu B, Lusingu JPA, et al. Comparison of artesunate-mefloquine and artemether-lumefantrine fixed-dose combinations for treatment of uncomplicated Plasmodium falciparum malaria in children younger than 5 years in sub-Saharan Africa: a randomised, multicentre, phase 4 trial. Lancet Infect Dis. 2016;16(10):1123-1133.

[17] You L, Ni B, Cao HM. Effects of low dose of ketotifen and chloroquine combination on the infrastructure of chloroquine resistant strain of Plasmodium yoelii. J Shanghai Univ. 2000;4(4):338-42.

[18] Somsak V, Damkaew A, and Onrak P Antimalarial Activity of Kaempferol and Its Combination with Chloroquine in Plasmodium berghei Infection in Mice. Jour of Path 2018; 2018;1- 7

[19] Ryley, J.F. and Peters, W. The antimalarial activity of some quinolone esters. Ann. Trop. Med. Parasitol. 1970; 84: 209-222.

[20] Knight, D.J. and Peters, W. The antimalarial action of N-Benzyl oxydihydrotriazines and the studies on its mode of action. Ann of Trop Med and Par. 1980; 74: 393-404.

[21] Peters, W. Rational methods in the search for antimalarial drugs. Trans. R. Soc. Trop. Med. Hyg. 1967; 61: 400410.

[22] Moreira de Oliveira EA, Lang KL. Drug Repositioning: Concept, Classification, Methodology, and Importance in Rare/Orphans and Neglected Diseases Jour of Appl Pharm Sci 2016 8(08), 157-165

[23] Thomas AM, Van Der Wel AM, Thomas AW, Janse CJ, Waters AP (1998). Transfection systems for animal models of malaria. Parasitol. Today, 14: 248-249.

[24] David AF, Philip JR, Simon IC, Reto B, Solomon N (2004). Antimalarial drug discovery: Efficacy models for compound screening. Nassture Rev., 3: 509-520

[25] Fidock DA, Rosenthal PJ, Croft SL, Brun R, Nwaka S. Antimalarial drug discovery: efficacy models for compound screening. Nat Rev Drug Discov. 2004;3(6):509-520.

[26] Tarkang PA, Appiah-Opong R, Ofori MF, Ayong LS, Nyarko AK. Application of multi-target phytotherapeutic concept in malaria drug discovery: a systems biology approach in biomarker identification. Biomark Res. 2016;4(1):25.

[27] Olanlokun JO, Babarinde CO and Olorunsogo 0. O. Toxicity of Anchomanes difformis, An Antimalarial Herb in Murine Models Eur Jour of Med Plants 2017; 20(3): 1-13

[28] Saxena R, Bhatia A, Midha K, Debnath M, Kaur P. Malaria: A Cause of Anemia and Its Effect on Pregnancy. World J Anemia. 2017;1(2):51-62.

[29] Chinchilla M, Guerrero O, Abarca G, Barrios M, Castro O. An in vivo model to study the anti-malaria capacity of plant extracts. Rev Biol Trop. 1998;46:1-7

[30] Sirak S, Fola AA, Worku L, Biadgo B. Malaria parasitemia and its association with lipid and hematological parameters among malaria-infected patients attending at Metema Hospital, Northwest Ethiopia. Path and Lab Med Intern. 2016;8:43-50

[31] Adekunle A.S., Adekunle O.C., Egbewale B.E Serum status of selected biochemical parameters in malaria: An animal model. Biomed Res 2007; 18 (2): 109-113 